\title{
Chapter 6 \\ European Universities and Educational and Occupational Intergenerational Social Mobility
}

\author{
Marek Kwiek
}

\subsection{Theoretical Contexts}

European higher education systems in the last few decades have been in a period of intensive quantitative expansion. Both participation rates and student numbers in most European countries are still growing - but are the chances of young people from lower socioeconomic classes to enter universities higher than before? Under massification conditions, are the chances of young people from poorer backgrounds actually increasing, relative to increasing chances of young people from higher socioeconomic classes and wealthier backgrounds? Are both overall social mobility and relative social mobility of underrepresented classes increasing at the same rate? That is a question about changing social mobility relative to the share of particular socioeconomic classes in the population as a whole. Social mobility in increasingly knowledge-driven economies is powerfully linked to equitable access to higher education. And the question of inequality in access to higher education is usually asked today in the context of educational expansion:

the key question about educational expansion is whether it reduces inequality by providing more opportunities for persons from disadvantaged strata, or magnifies inequality, by expanding opportunities disproportionately for those who are already privileged.

(Arum et al. 2007: 1)

Educational expansion, in most general terms, and in the majority of European countries studied, seems to be reducing inequality of access. There are ever more

\footnotetext{
M. Kwiek (訩

Center for Public Policy Studies and UNESCO Institutional Research and Higher Education Policy, University of Poznan, Poznan, Poland

e-mail: kwiekm@amu.edu.pl
} 
students with lower socioeconomic backgrounds and ever more graduates whose parents had only primary education credentials. The chances of the latter to enter higher education are increasing across Europe but are still very low. The intergenerational patterns of transmission of education are still very rigid across all European systems: the offspring of the low educated is predominantly low educated; the offspring of the highly educated is predominantly highly educated. Structurally similar patterns can be shown for occupations: the offspring of those in the best occupations predominantly takes best occupations, and the offspring of those in the worst occupations predominantly takes the worst occupations, across all European countries ("best" being structurally similar and linked to both middle-class earnings and lifestyles in Europe).

Equitable access to higher education is linked in this chapter is empirically linked to the social background of students viewed from two parallel perspectives educational background of parents and occupational background of parents - and studied through the large-scale EU-SILC (European Union Survey on Income and Living Conditions) dataset.

It is generally assumed in both current scholarly and policy literature that major higher education systems in the European Union will be further expanding in the next decade (Altbach et al. 2010; King 2004; Morgan et al. 2009; Trow 2007; Attewell and Newman 2010; EC 2011). Expanding systems, in general terms, tend to contribute to social inclusion and equity because the expanding pie, as argued in a recent cross-national study, "extends a valued good to a broader spectrum of the population" (Arum et al. 2007: 29). More young people go to universities and graduate from them, across all socioeconomic classes. At the same time, as Anna Vignoles argued in the UK context of high fees,

It remains the case that young people from poorer backgrounds are very much underrepresented, relative to their share of the population as a whole. The need to further widen participation for these poorer students ... therefore remains a pressing policy issue. (Vignoles 2013: 112)

In the knowledge economy discourse, the expansion of higher education systems is key and high enrolment rates in the EU have been viewed as a major policy goal by the European Commission throughout the last decade, at least since the Lisbon Strategy was launched in 2000, followed by the Europe 2020 strategy launched in 2010. The European Commission's recent Communication (September 2011) states again that attainment levels in higher education in Europe

are still largely insufficient to meet the projected growth in knowledge-intensive jobs, reinforce Europe's capacity to benefit from globalisation, and sustain the European social model. (EC 2011: 3)

The empirical data from both the EU-27 and the OECD area demonstrate that indeed educational expansion has been in full swing across the whole developed world in the last two decades (and that educational contraction in the next decade is a serious policy issue for only several countries: most notably, Poland in the European Union and Korea and Japan in Asia. The three countries are exceptions to the general rule in which further educational expansion is expected, though, 
as discussed further in Kwiek (2013a, b)). The expansion has several new dimensions which may include, to a degree depending on a country, nontraditional routes to higher education, nontraditional age students, shorter study programs (bachelor level rather than masters level), and lifelong learning opportunities. The expansion in Europe thus includes both new students and returning students, and the social base of higher education systems is expected to be further enlarged.

The starting point in research into equity in access to higher education for young Europeans, from a European policy perspective, could be the London Communiqué of the Bologna Process (2007) which states (reflecting current social sciences research on equitable access to higher education, social stratification, and social justice) that "the student body ... should reflect the diversity of our population" (London Communique 2007). Similarly, the Bucharest Communiqué (2012: 2) stresses that

The student body entering and graduating from higher education institutions should reflect the diversity of Europe's populations. We will step up our efforts towards underrepresented groups to develop the social dimension of higher education, reduce inequalities and provide adequate student support services, counselling and guidance, flexible learning paths and alternative access routes, including recognition of prior learning.

Cross-national comparisons of equitable access to higher education and its changing patterns over time can be shown based on the EU-SILC and, in particular, based on its 2005 module on "The Intergenerational Transmission of Poverty."

Equity in access to higher education, or, in other words, more open intergenerational social mobility through higher education, is positively correlated with human capital development (as well as the development of human capabilities) and with the economic competitiveness of nations (Kwiek 2012b). As is well known from comparative studies conducted by both the World Bank and the OECD, both the long-term social and long-term financial costs of educational failure are high: those without skills, to fully participate socially and economically in the life of their communities, generate higher costs in the areas of healthcare, income support, child welfare, and security. Equitable access to higher education enhances social cohesion and trust and increases democratic participation (and all those dimensions are systematically measured by the OECD through their indicators). There is a positive correlation between the highest levels of education attained and democratic participation, voting patterns, health, and other indicators of well-being. This is what human capital approach stresses.

But the same positive correlations are shown, in a different social science vocabulary and based on different founding principles, in the capabilities approach. The capabilities approach - as an "alternative perspective" (Schneider and Otto: 2009: 8; see Walker 2006: 144) and a "fundamental alternative to neoliberalism" (Otto and Ziegler 2010: 232) - rightly stresses that education is "far more than human capital," "expands capabilities and functionings," "enlarges valuable choices," "influences democratic social change by forming critical voices," "involves obligations to others," "requires pedagogical process freedom," and "fosters agency and well-being" (Walker 2010a: 159-167; see Otto and Ziegler 2010; Nussbaum 2010, 2011; Walker and Unterhalter 2007). What Melanie Walker terms fundamental 
elements of a "just education" are far more resistant to be measured than the traditional OECD indicators. The difference between the human capital approach and the capabilities approach in their account of education is clear: "if education makes someone a better producer able to contribute more to national income then education is deemed successful. In the capability approach a human capital basis for education is useful but limited" (Walker 2010a: 159). Amartya Sen in Development as Freedom makes a clear link between capabilities and freedom: "a person's capability refers to the alternative combinations of functionings that are feasible for her to achieve. Capability is thus a kind of freedom: the substantive freedom to achieve alternative functioning combinations" (Sen 1999: 75). The notion of capability is central for Sen because someone's "actual functionings do not, in themselves, tell us very much about how well off she is. ... The capability approach captures differences by looking behind the actual functionings at the opportunities or freedom people have to function" (Brighouse and Unterhalter 2010: 199-200). Or as Hans-Uwe Otto (2009: 48) put it succinctly,

instead of looking at the means, the capabilities approach focuses on what individuals are capable of doing. ... The capabilities approach distinguishes between the individual's dispositions and the external conditions that help these dispositions to manifest in reality.

Functionings refer to whether individuals actually do or do not do something specific. In contrast, the capabilities perspective "addresses the objective set of possibilities of realizing different combinations of specific qualities of functionings" (Otto 2009: 49). In the capability approach, there is a rich understanding of agency: "each person is a dignified and responsible human being who shapes her or his own life in the light of goals that matter" (Walker 2010a: 167).

A particular strength in the capabilities approach, as Elaine Unterhalter and Melanie Walker (2007: 251) argue, is that

while broadly oriented to justice, through its emphasis on capability (potential to function) it does not prescribe one version of good life but allows for plurality in choosing lives we have reason to value. The approach emphasizes the importance of capability over functioning not a single idea of human flourishing, but a range of possibilities and a concern with facilitating valuable choices. Above all, the capability approach offers a freedoms-focused and equality-oriented approach to practicing and evaluating education and social justice in all education sectors and in diverse social contexts.

The capability approach, as opposed to resourcist approaches, looks at a relationship between the resources people have and what they can do with them. Consequently, a person's capability refers to the alternative combinations of functionings that are feasible for the person to achieve (Unterhalter and Brighouse 2007: 74). As they emphasize, defending the capability approach against Thomas Pogge's objections,

One of the apparent advantages of the capability approach over its rivals is its sensitivity to inequalities of natural endowments. The value of resources is usually defined without regard to what their holder can do with them; but the capability approach always looks at how well an individual can convert her bundle of resources into functionings. (Unterhalter and Brighouse 2007: 75) 
One important remark has to be made, though. The human capital approach has been providing ideas, standard vocabulary, and related empirical data through large-scale datasets about higher education for more than four decades. The capability approach, in contrast, has been more systematically applied to higher education relatively recently (see especially Walker 2006, 2010a, b; Flores-Crespo 2007; Unterhalter 2010, 2013; Brighouse 2010; Boni and Walker 2013). Although Amartya Sen was never focused on universities, Martha C. Nussbaum was, with her recent Not For Profit: Why Democracy Needs the Humanities (2010) in the forefront. Consequently, the capabilities approach could potentially provide new interesting intellectual tools to deal with old higher education concerns, including both equity and social mobility. As Walker concludes in her book on what she terms "higher education pedagogies,"

\footnotetext{
the capability approach addresses both processes and outcomes of learning and pedagogy. It robustly challenges the narrowness of human capital theory in which human lives are viewed as the means to economic gains. ... Above all, it points to a problem and suggests a practical approach. It requires not only that we talk about and theorize change but that we are able to point to and do change through the focus on beings and doings in and through higher education. (Walker 2006: 144, emphasis in original)
}

Although at the moment the capabilities approach does not seem to contribute significantly to mainstream higher education research, and the community of capability approach researchers in higher education is small and limited to a few countries, its future potential should not be disregarded. So far, the number of both books and papers linking, sometimes indirectly, higher education and capabilities approach is very small: by the end of 2013, their total number available in English does not seem to exceed 50, and they come from mostly the same scholars. But higher education research as a field of studies has always been open to theoretical and methodological influences of new approaches. The future will show how this approach can contribute to the field and whether a human development and capabilities approach perspective are indeed powerful enough to inform "policies and practices" of higher education (Boni and Walker 2013: 7). As Alejandra Boni and Melanie Walker stress, "human development values, capabilities, agency, all are key concepts to re-imagine a different vision of the university, beyond the goal to prepare people as part of a workforce" (Boni and Walker 2013: 5).

The influence of capabilities approach on national politics and welfare policies, in contrast to its influence on research into higher education, can already be substantial, becoming in some countries (e.g., Germany) a part of the "official political agenda" (Otto and Ziegler 2010: 232). It might be possible that the capabilities approach is useful for changing social practices, not only or not exclusively for theorizing about social practices. Such a possibility is clearly suggested by Walker (2010a: 168) when she argues that "capability formation in and through education would widen possibilities and struggle against inequality. It would have an orientation to global justice," especially if Karl Polanyi's "pendulum effect" (swinging back and forth between the state and the market) is at work in European societies, as suggested elsewhere (Walker and Boni 2013: 22-24). Elaine Unterhalter's (2010: 95-108) 
three types of pedagogies need to be distinguished: "pedagogies of consequence" (linked to human capital approach and an instrumental view of higher education), "pedagogies of construction" (higher education asserting and practicing the importance of moral equality and justice as supreme values), and "pedagogies of connection" (concerned with equality). An instrumental view of higher education no longer suffices in reimagining an institution of the university under globalization pressures.

Interestingly, Elaine Unterhalter and Vincent Carpentier (2010: 3-9) refer to inequalities in and through higher education not as a "dilemma" but as a "tetralemma" that might guide what is to be done in four rather than in two different directions. The tetralemmas of higher education, or the four different elements pulling higher education apart, are the following: economic growth, equity, democracy, and sustainability. And the question is: how can we hold together aspirations for all of them at the same time? Each of them is pulling higher education in different directions so that resolving one dimension means "compromising or abandoning at least one other" (Walker and Boni 2013: 16). Equality (and inequality) is at the very center of the tetralemma and inequality may produce instability which undermines democracy. Without suitably educated citizens, no democracy can remain stable (Nussbaum 2010: 10). Equitable access to higher education and social mobility through higher education are a fundamental part of the tetralemma. As they argue, "higher education is both potential source and solution to inequalities which confront us" (Unterhalter and Carpentier 2010: 16).

Traditionally, education, and in knowledge economies especially higher education, is the main channel of upward social intergenerational mobility. It enables individuals to cross class boundaries between generations. Education, and higher education in particular, enables intergenerational social mobility to a higher degree in more equitable societies and to a lower degree in less equitable societies.

An equitable or mobile society seems to be a relational (or positional) notion: some societies are clearly more equitable or mobile than other societies, and some clusters of countries seem to be more equitable or mobile than other clusters of countries. Intergenerational social mobility reflects the equality of opportunities. Younger generations "inherit" education and "inherit" occupations from their parents to a higher degree in less mobile societies. Young Europeans' educational futures and occupational futures look different in more and in less mobile European societies. As defined by the OECD:

\footnotetext{
Intergenerational social mobility refers to the relationship between the socioeconomic status of parents and the status their children will attain as adults. Put differently, mobility reflects the extent to which individuals move up (or down) the social ladder compared with their parents. A society can be deemed more or less mobile depending on whether the link between parents' and children's social status as adults is looser or tighter. In a relatively immobile society an individual's wage, education or occupation tends to be strongly related to those of his/her parents. (OECD 2010: 4)
}

In the majority of higher education systems in Europe, higher educational credentials lead to "better jobs" and better life chances (for "good jobs" in the USA, see Holzer et al. (2011)). Nevertheless, from a theoretical perspective of "positional 
goods," developed for the first time in the 1970s by a British economist, Fred Hirsch, there is always "social congestion" in every society: the number of good jobs (for instance, prestigious white-collar jobs leading to high incomes or to stable middle-class lifestyles) in a labor market system is always limited, and top jobs in a given system will always be limited, no matter how well educated the workforce is (see Kwiek 2006, 2010). The division of economy in particular EU member states into major sectors (e.g., manufacturing, services, agriculture in OECD categories, or into major nine occupations, and "professionals" vs. all other types of occupations in a United Nations terminology in particular) and its changes over time should be an important point of references in all "new skills for new jobs" theoretical exercises presented by the European Commission linking the growth in jobs requiring high skills with the growth in students numbers. In general, European societies, interested in skills and jobs, should bear in mind that higher education is a powerfully positional good: it may define the position of its possessors only relative to other in the labor market. Educational expansion leads to an increased number of highly qualified people who find it increasingly difficult to have stable, middle-class jobs, across the whole developed world.

Harry Brighouse and Elaine Unterhalter (2007: 78-83, 2010: 207-212) presented a model to measure justice in education, grounded in both Rawl's social primary good theory and Amartya Sen's and Martha Nussbaum's capabilities approach and treating both approaches as complementary. In their model, the three overlapping fields that intersect with freedom (agency freedom and well-being freedom) relate to three different aspects of the value of education. These are the instrumental value of education, the intrinsic value of education, and the positional value of education. The instrumental value helps to secure work at a certain level and political and social participation in certain forms; the intrinsic value refers to the benefits the person gets from education which are not merely instrumental for some other benefit they may be able to use to get it. And the positional value of education, most important to us here, is

insofar as its benefits for the educated person depend on how successful she has been relative
to others. For example, for any individual child aiming to enter a prestigious university, for
which there is a fixed number of places, what matters to her is not at all how successful she
has been in school, but only how successful she has been relative to her competitors.
(Brighouse and Unterhalter 2010: 210 , emphasis mine)

In a very similar vein, educational expansion in labor markets already saturated with higher education graduates has certainly different consequences than educational expansion in labor markets which are still far away from a state of saturation (the best example being monetary rewards from higher education in such clusters of countries as Central Europe on the one hand and the Nordic countries on the other). On average, CEE countries still have considerably less educated labor force, so - one can assume - monetary rewards from higher education, or wage premium for higher education, are higher. Nonmonetary rewards include, for instance, low levels of unemployment for higher education graduates, combined with relatively faster transitions from unemployment to employment, as analyses of the EU-SILC data demonstrate. 
Also, any research, including present research based on EU-SILC microdata, should be cognizant of the potential limit to individual benefits from higher education attainment level as an individual shield against unemployment or as an individual life strategy inevitably leading to traditional middle-class lifestyles. From the theoretical perspective in which higher education credentials are "positional goods," while collective, or public, benefits from educational expansion are increasing, individual, or private, benefits from educational expansion, as viewed, e.g., through the proxy of wage premium for higher education, do not have to be increasing. In some European systems, as reported by the OECD, the wage premium has been consistently high, and increasing, on a global scale, in the last decade. These are postcommunist Central European economies, such as Poland, the Czech Republic, Slovakia, and Hungary (Kwiek 2001). In other systems, where educational expansion has started (much) earlier, the wage premium for higher education is much lower and either stable or decreasing (for instance, in the Nordic countries). There are several interrelated explanations but one of them is the "positional goods" argument according to which the advantage of higher education credentials in the labor market is relative or positional: if collective efforts of ever-increasing numbers of young people are focused in the same direction, individual gains from individually rational life strategies do not lead to expected results (Brown et al. 2011; Hirsch 1976).

The EU-SILC dataset offers the possibility to study inequality of educational outcomes and relevant coefficients: contrasting those young Europeans whose father (and/or mother) had tertiary education credentials with those whose father (and/or mother) had compulsory education credentials or less. In more equitable national educational regimes, not only educational trajectories of young Europeans with different social backgrounds will be more similar - but also their labor market trajectories will be more similar. By contrast, in less equitable national educational regimes, both educational and labor market trajectories of young Europeans with different social backgrounds will be markedly different. In short, the chances of young Europeans from lower socioeconomic strata to attain higher education will be closer to the chances of young Europeans from higher socioeconomic strata in more equitable systems and in more equitable societies. Alternatively, higher education will be less "inherited," that is, less dependent on parents' (father's or mother's or both) education in more equitable societies.

Two questions need to be separated. One question is about labor market trajectories of young Europeans (aged 15-34, for the purposes of the present research). Another question is how labor market trajectories are determined by social circumstances and family background in particular. In relatively more equitable (just, fair, open, mobile, etc.) systems, the role of social background is less important than in relatively less equitable (just, fair, open, mobile, etc.) systems. (There are long-standing discussions in social science research what social "justice" and "fairness" in access to higher education mean and what "openness" of higher education which leads to higher "intergenerational social mobility" means.) Consequently, the EU-SILC data allow to study both the "inheritance" of education and the "inheritance" of occupations: occupations will be less "inherited," that is, less dependent on parents' 
(father's or mother's or both) occupations in more equitable societies. Cross-country differences can be shown, and especially two contrasting clusters of countries, with very low as opposed to very high social mobility, can be identified.

Different lifetime additional earnings depending on the highest level of education attained by individuals, consistently reported for the OECD area, refer not only to higher education degree taken (usually from the arts and humanities at the bottom end and medicine at the top end of the spectrum) but also to open or closed access to occupations and professions based on social and economic strata of origin (including different labor market aspirations and values and beliefs originating also from social environment in the pre-higher education periods of study). Consequently, while lifetime additional earnings refer to levels of education attained, the EU-SILC data provide clues about intergenerational mobility both in terms of educational levels of respondents and their parents and in terms of occupations of respondents and their parents.

The theoretical underpinning of the present research is the idea that higher education credentials, in the times of massification, should be increasingly viewed as (Fred Hirsch's) "positional goods": they increase the chances of better labor market trajectories only to a certain point of saturation behind which they become a must, a starting point in competition between individuals holding it, rather than a clear competitive advantage. As "social congestion" increases, that is, the number of higher education graduates increases, the role of credentials as signaling mechanisms (about abilities of graduates) is changing: as in Hirsch's memorable metaphor, standing on tiptoes in a stadium does not help to get a better view if all others around also stand on tiptoes. At the same time, not having higher education credentials, like not standing on tiptoes, is a serious drawback in the labor market. So credentials are sought by an ever-increasing share of young Europeans, even though their economic value may be, in many systems and increasingly so, questioned. Stable or increasing participation rates in higher education mean a bigger share of populations with higher education credentials seeking traditional white-collar occupations. What especially matters is the question whether the share of students from underrepresented strata in the higher education population is increasing (as we know that their numbers are increasing).

As OECD data for the last decade show, the overall higher education attainment for the population aged 25-64 has been increasing throughout the OECD area in the 1997-2009 period, with the OECD average annual growth rate of $3.7 \%$ and with the EU-21 average annual growth rate of $3.9 \%$. Average annual growth in the proportion of those with a tertiary education has exceeded $5 \%$ in four European countries: Ireland, Luxembourg, Poland, and Portugal. The proportion of the population that had not attained upper secondary education decreased by $5 \%$ or more per year in five European countries: Hungary, Luxembourg, the Netherlands, Poland, and the Slovak Republic. Most of the changes in educational attainment have occurred at the low and high ends of the skills distribution, largely because older workers with low levels of education are moving out of the labor force and as a result of the expansion of higher education in many countries in recent years. As OECD's Education at a Glance explains, this expansion has generally been met by 
an even more rapid shift in the demand for skills in most OECD countries: the demand side can be explored in labor market indicators on employment and unemployment, earnings, incentives to invest in education, labor costs and net income, and transition from school to work, all covered in this OECD volume (OECD 2011).

What works on an individual basis, and especially before the level of massification or universalization of higher education is reached, does not seem to work from a larger social perspective: individual efforts may be largely lost if all young people undertake the same efforts of getting higher education credentials, as the efforts finally may not lead to increasing individual life chances. The pool of "good jobs" seems to be restricted in Europe, as elsewhere, and the idea that higher education is leading to middle-class lifestyles and standards of living for everyone may be increasingly misleading, as Brown et al. (2011) demonstrate (for Poland, see also Kwiek (2012b)).

Both in the USA and in Europe, the standard of living of young people is threatened to be lower than the standard of living of their parents, especially for those from the middle classes, as Robert Frank argues in Falling Behind: How Rising Inequality Is Harming the Middle Classes (2007). The "positional goods" perspective (represented by Fred Hirsch and Robert Frank among labor economists, and Phillip Brown and Hugh Lauder among sociologists of education; for the first time applied to education in Simon Marginson's landmark study from 1997, Markets in Education) Marginson (1997) needs to be born in mind in any cross-country research based on the EU-SILC data.

The initial hypothesis of the present research was that in those European countries where higher education has been more expanded, there is more equality in achieving higher education by social background - but there are also accompanying diminishing occupational and wage returns from higher education. The OECD data do not suffice to research the interrelations between the two and it is useful to strengthen this line of research by the empirical evidence derived from the EU-SILC. The EU-SILC dataset thus provides new opportunities for Europe-wide mapping of inequality.

\subsection{Intergenerational Social Mobility: A European Union Survey on Income and Living Conditions (EU-SILC)}

The European Union Survey on Income and Living Conditions (EU-SILC) collects microdata on income, poverty, and social exclusion at the level of households and collects information about individuals' labor market statuses and their health. The database includes both cross-sectional data and longitudinal data. For most countries of the pool of 26, the most recent data available come from 2007 to 2008. The 2005 module on "The Intergenerational Transmission of Poverty" of the EU-SILC provides data for attributes of respondents' parents during their childhood (age 14-16). The module reports the educational attainment level and the occupational status of each respondents' father and mother. As reported by the OECD, 
in almost all European OECD countries, there is "a statistically significant probability premium of achieving tertiary education associated with coming from a highereducated family, while there is a probability penalty associated with growing up in a lower-educated family" (Causa and Johansson 2009b: 18). We shall follow these intuitions, well known from comparative social stratification studies. Fairness in access to higher education in Poland, a country taken as an example, is linked in this section to intergenerational transmission of educational attainment levels and occupational statuses of parents from a European comparative perspective. If Polish society is less mobile than other European societies, then the need for more equitable access to higher education in Poland is greater than elsewhere in Europe. While absolute numbers can speak by themselves, I assume here that the numbers tell us more in a European comparative context.

In technical terms, I conduct a brief assessment of the relative risk ratio of "inheriting" levels of educational attainment and "inheriting" occupations in transitions from one generation to another generation in Poland from a cross-national perspective. Relative risk ratios show how many times the occurrence of a success is more probable in an individual with a given attribute than in an individual without a given attribute. In the case studied here, "success" is the respondent's higher education and the attribute is parents' higher education. Relative risk ratios (presented in Fig. 6.1) show how an attribute of one's parents makes it more likely that the respondent (offspring) will show the same attribute (see Causa and Johansson 2009a, b).

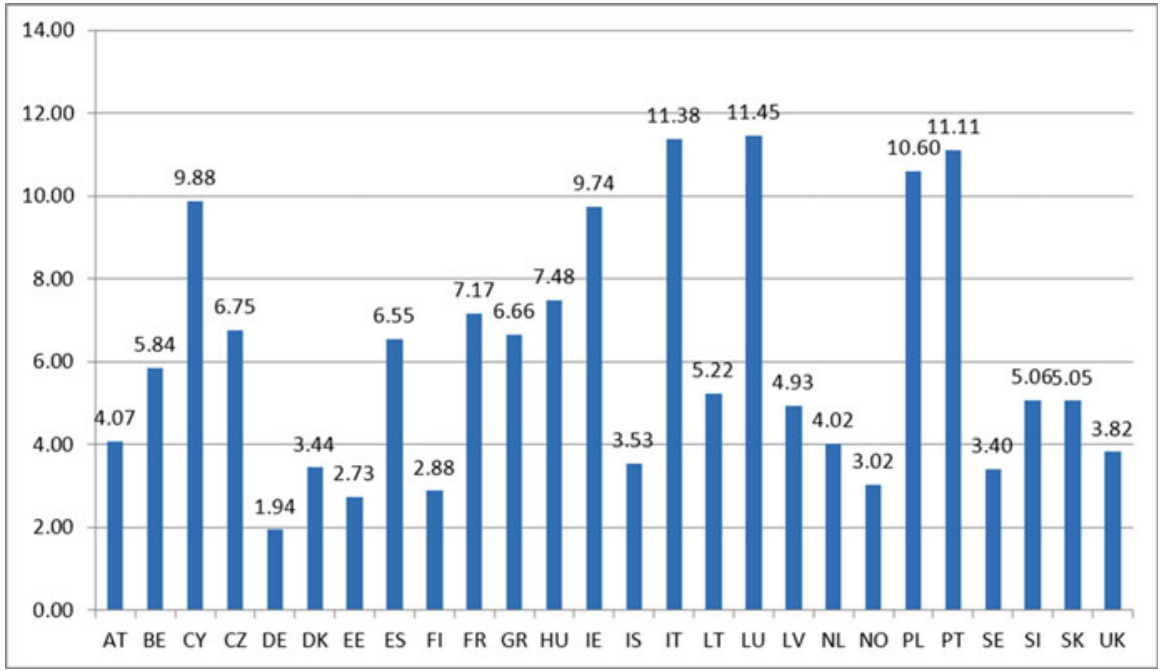

Fig. 6.1 Relative risk ratio for persons with higher education in relation to their father's higher education (Source: own study based on EU-SILC 2005 module on "The intergenerational transmission of poverty.") (The cross-country results are presented for the 35-44-year-old cohort. The module is based on data from personal interviews only. Variables analyzed were PM040: "Highest ISCED level of education by father," PM060: "Main activity status of father," and PM070: "Main occupation of father") 
Similarly, in OECD analyses, the risk ratio of achieving tertiary education is defined as "the ratio of two conditional probabilities. It measures the ratio between the probability of an offspring to achieve tertiary education given that her/his father had achieved tertiary education and the probability of an offspring to achieve tertiary education given that her/his father had achieved below-upper secondary education. Father's educational achievement is a proxy for parental background or wages" (Causa and Johansson 2009b: 51).

Relative risk ratios were estimated using logistic regression analysis for the weighted data. A binomial model was used. Multinomial-dependent variables were dichotomized and separate models were constructed. The choice of independent variables was conducted using a backstep method and the Wald criterion.

Generally, there are four educational intergenerational social transitions and two occupational intergenerational transitions of interest to us here. The probabilities of educational transitions are calculated for the following cases: fathers with primary education and respondents with primary education, fathers with tertiary education and respondents with primary education, fathers with primary education and respondents with tertiary education, and fathers with tertiary education and respondents with tertiary education. And the probabilities of occupational transitions are calculated for two cases only: respondents with an elementary occupation, in relation to their fathers' occupation (ISCO groups 1 through 9), and respondents with an ISCO group 1 occupation ((1) legislators, senior professionals, (2) professionals, and (3) technicians and associate professionals), in relation to their fathers' occupations.

Among European countries, Poland has one of the highest relative risk ratios (10.6) for persons with higher education to have their parents with higher education, meaning that it is highly unlikely for children to have higher education if their parents did not also achieve the same level of education. In Poland, for a person whose parents had higher education, the probability of attaining higher education is 10.6 times higher than for a person whose parents had education lower than higher education. There are only four European systems that markedly stand out in variation (Poland, Portugal, Italy, and Ireland, plus two tiny systems of Luxembourg and Cyprus): in all of them, the probability that an individual who has attained higher education has parents who have attained higher education is about ten times higher than a person whose parents did not. While higher education is being "inherited" all over Europe, in Poland, the probability is on average almost two times higher than in other European countries (the average for 26 countries is 6.06, and the average for 8 postcommunist countries is 5.97). The details are given below in Fig. 6.1.

On the basis of the EU-SILC data, one can follow the transmission of education and the transmission of occupations across generations and see to what extent parental educational and occupational backgrounds are reflected in their offspring's educational and occupational backgrounds. Educational status and occupational status are strong attributes carried across generations (Archer et al. 2003; Breen 2004).

Figure 6.2 below shows the probability of respondents achieving higher education given that their parents had achieved a primary level of education. In more mobile societies, the probability will be higher; in societies in which intergenerational mobility is lower, the probability will be lower. As can be seen, there is a major 


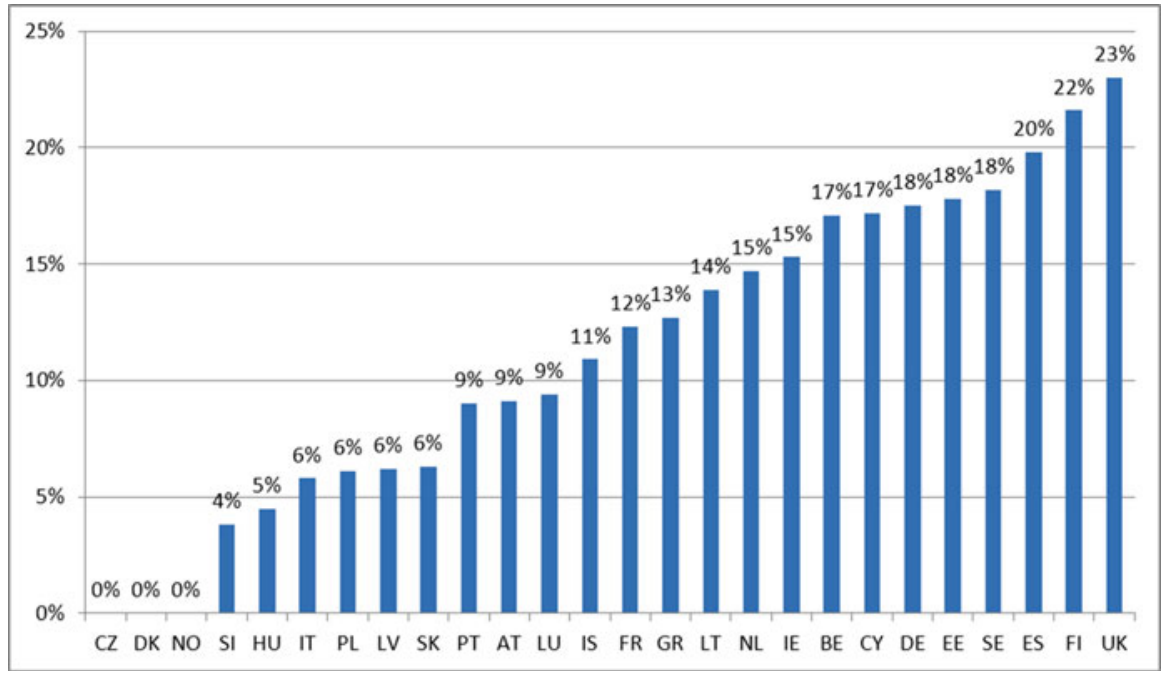

Fig. 6.2 Transition from parents' primary education to respondent's higher education (Source: own study based on EU-SILC 2005 module on "The intergenerational transmission of poverty" ( $0 \%$ for $\mathrm{CZ}, \mathrm{DK}$, and NO results from a too low number of respondents in these countries))

divide between a cluster of countries in which there is low probability of upward mobility for this subpopulation - in the range of 4-6\% - and a cluster of countries in which the probability of upward mobility for the same subpopulation is three to four times higher and the probability of a "generational leap" in education between generations for those born in low-educated families is three to four times higher, in the range of 17-23\%. The "low probability" cluster includes Poland and several other former communist countries, as well as Italy. The "high probability" cluster includes the Nordic countries, Belgium, Germany, Estonia, Spain, and the UK (no distinction in the dataset can be made between various types of higher education so that the question of "access to what" from an intergenerational perspective cannot be answered on the basis of the EU-SILC). Other countries are in the middle. The probability of upward intergenerational mobility for young people from low-educated families through higher education, from a comparative perspective, is clearly very low in Poland. The percentage of people with higher education whose parents had primary education is only $6 \%$; the remaining $94 \%$ of people whose parents had primary education never attained higher education.

One can also look at the rigidity of educational backgrounds across generations or the transmission of the same level of education (from primary to primary, from higher to higher) across generations. What is particularly relevant here is the inheritance of higher education across generations. Figure 6.3 below shows that in all 26 European countries studied (except Slovenia), the probability of having attained higher education if one's parents have also attained higher education is more than $50 \%$. The lowest range $(50-60 \%)$ dominates in several postcommunist countries, 


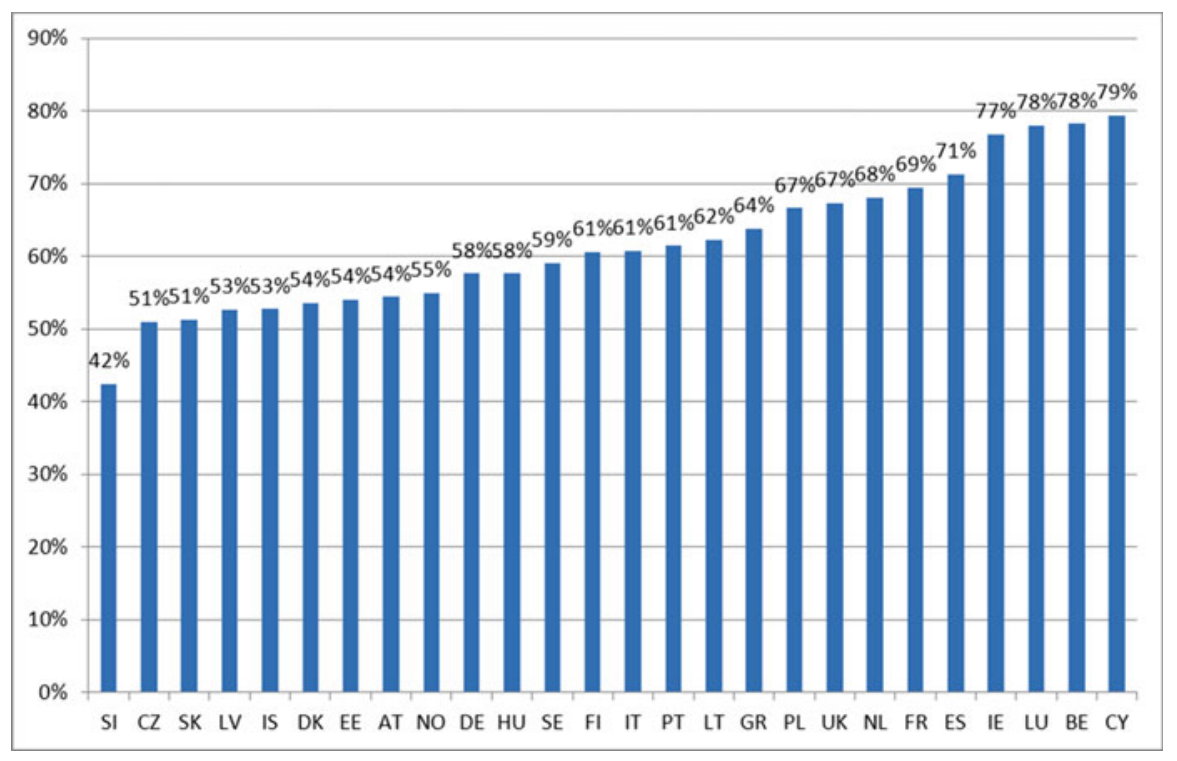

Fig. 6.3 Transition from parents' higher education to respondent's higher education (Source: own study based on EU-SILC 2005 module on "The intergenerational transmission of poverty")

as well as in Denmark, Austria, Norway, Germany, and Sweden. The highest range (70-79\%) is shown only for Spain, Ireland, and Belgium, as well as two small systems of Luxembourg and Cyprus. Poland $(67 \%)$ is in the upper-middle range of 65-70\%, and ninth from the top: $67 \%$ of people whose parents had higher education managed to attain higher education. The remaining $33 \%$ attained the level of education which was lower than higher education.

Analyses of the transmission of levels of education across generations can also be supplemented with analyses of the transmission of occupation across generations, with similar results for Poland. This article uses ISCO-88 (International Standard Classification of Occupations) basic occupational groups (nine major groups) and, following recent EUROSTUDENT IV study (2011), applies the following hierarchy of workers:

- Highly skilled white-collar ((1) legislators, senior professionals, (2) professionals, and (3) technicians and associate professionals)

- Low-skilled white-collar ((4) clerks, (5) service workers and shop and market sales workers)

- Highly skilled blue-collar ((6) skilled agriculture and fishery workers, (7) craft and related trades workers)

- Low-skilled blue-collar ((8) plant and machine operators and assemblers, (9) elementary occupations)

Analyses performed with reference to ISCO-88 group 1 occupations ("legislators and senior professionals," translated in Fig. 6.4 into "highly skilled white-collar") 


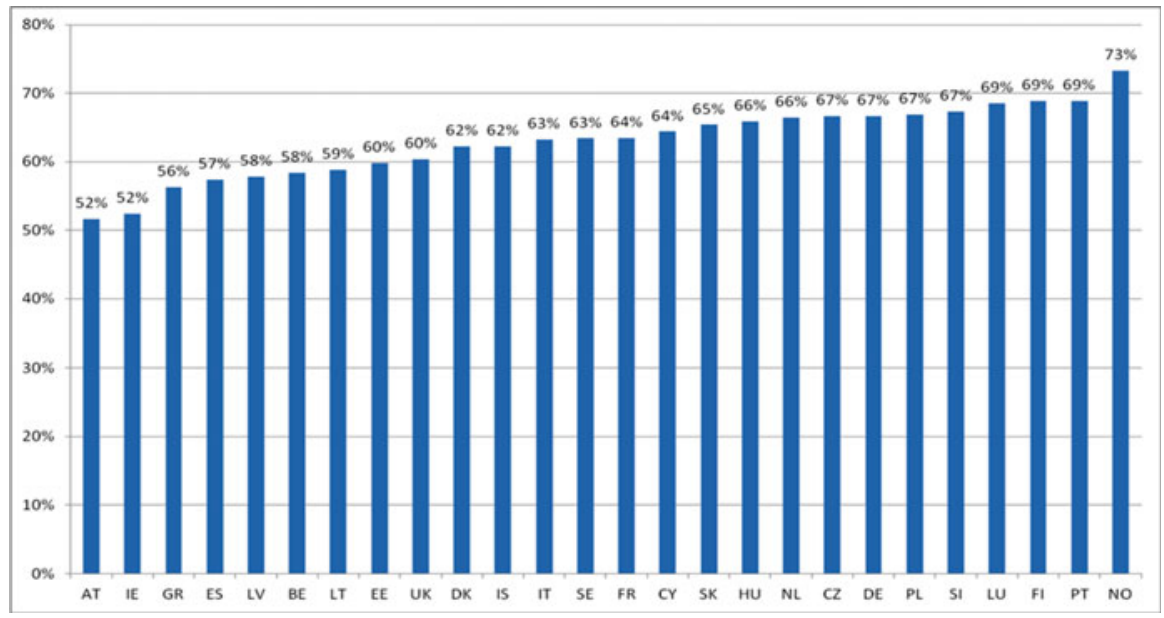

Fig. 6.4 Transition from parents' highly skilled white-collar occupation to respondent's highly skilled white-collar occupation. (The analysis presented in Figure 12 aggregated the nine ISCO-88 basic occupational groups, following recent EUROSTUDENT IV study (Eurostudent 2011: 55), into the following four groups of workers: "highly skilled white-collar" ( 1 legislators, senior professionals, 2 professionals, and 3 technicians and associate professionals), "low-skilled whitecollar" ( 4 clerks, 5 service workers and shop and market sales workers), "highly skilled blue-collar" (6 skilled agriculture and fishery workers, 7 craft and related trades workers), and "low-skilled blue-collar" ( 8 plant and machine operators and assemblers, 9 elementary occupations)) (Source: own study based on EU-SILC 2005 module on "The intergenerational transmission of poverty")

in relation to parents' occupation show that while overall in Europe the "inheritance" of highly skilled white-collar occupations is high, and it is generally in the 50-70\% range, in Poland it is very high and reaches $67 \%$.

In the case studied here, the success is respondent's group 1 occupation and the attribute is parents' group 1 occupation. Relative risk ratios show how an attribute of one's parents makes it more likely that the respondent will show the same attribute. Table 6.1 in the Data Appendix shows the relative risk ratio for persons from ISCO-88 highest occupational group ("legislators and senior professionals" or LE, shadowed) in relation to their fathers' occupation. For instance, for Poland, the probability that a person whose father was a legislator or senior professional will have the same category of occupation is 3.32 times higher than in the case of a person whose father had a different occupation; the probability that a person whose father had an "elementary" (EL) occupation will have a legislator or senior professional occupation is 1.49 times lower than in the case of a person whose father had occupation other than EL. Table 6.2 in the Data Appendix shows the relative risk ratio for persons from ISCO-88 lowest occupational group ("elementary" or EL, shadowed) in relation to their fathers' occupation. For Poland, the probability that a person whose father had an elementary occupation to have the same category of occupation is 2.11 times higher than in the case of a person whose father had a different occupation. Figure 6.4 shows that, for Poland, $67 \%$ of persons whose fathers had highly skilled white-collar occupations also have the same occupation. 
The remaining $33 \%$ of those persons have different occupation. In Poland, the level of "inheriting" higher education and highly skilled white-collar occupations is high, and successful transitions across generations from primary education to higher education and from low-skilled blue-collar occupations to highly skilled white-collar occupations are rare.

Thus, upward educational social mobility in Poland (from a longer perspective and despite the 1990-2005 expansion period in higher education) is still limited, and the level of inheritance of both educational status and occupational status across generations is quite high, compared with other European countries. The changes in mobility among social strata are long term, and the recent expansion period in higher education is still short enough to change the basic social structure in Poland (on the role of privatization of higher education in the expansion, see Bialecki and Dabrowa-Szefler (2009), Kwiek (2014)). Both the highest educational attainment levels and the most socially and financially rewarded occupations ("highly skilled white-collar") are inherited in Poland to a stronger degree than in most European countries, except for most postcommunist countries. Based on above analyses, Poland seems to differ more from more socially mobile Western European systems and less from most socially immobile postcommunist systems in its educational social mobility than traditionally assumed in the research literature (e.g., Domański 2000; Mach 2004; Baranowska 2011). Polish society in general is less mobile compared with most Western European systems because the links between parents' and children's social status as adults (in both educational and occupational terms) are tighter. While the expansion period substantially increased equitable access to higher education in Poland, upward social mobility viewed from a long-term perspective of change across generations is still limited. Consequently, from a European comparative perspective, there is much greater need for further fair and increased access to higher education than commonly assumed in educational research (for a Polish higher education massification context from which the above data are derived, see Kwiek (2012a, 2013b), and for a European context, see Kwiek (2009a, 2013a)).

\section{Conclusions and Directions for Further Research}

There are at least three major directions for further research.

One research direction is linking higher education with labor market trajectories through academic fields of study, with additional lifetime earnings different for different academic degrees viewed horizontally (masters in one study area vs. masters in a different area) rather than vertically (masters in all areas vs. bachelors in all areas). The difference between following labor market trajectories by educational levels and by fields of study within the same educational level (e.g., at the bachelors and masters levels in different fields of study) is significant. The second research direction is a combination 
of insights from the EU-SILC dataset and from two large-scale European datasets about European university graduates and about European professionals, as studied through surveys in 12 European countries in the 2000s, CHEERS and REFLEX. And the third research direction is a study of lifelong learning.

Thus, the first task for future research is linking higher education with the labor market and labor market trajectories (including transitions between employment, unemployment, and inactivity) through academic fields of study. Not only the status of being employed/unemployed/inactive in the labor market is linked to the level of education (which EU-SILC data clearly show) - but the labor market status and its transitions are also substantially linked to fields of study. The national average wage premium from higher education, private internal rate of return (IRR) in higher education, and other related indicators measured over the years by OECD do not show the difference between fields of studies. So far, this dimension has not been systematically explored, mostly due to the lack of European data in a comparable format. And average additional lifetime earnings are substantially different for different degrees, as various national or global labor market studies show. While overall average additional lifetime earnings for higher education seem substantial in most countries, they are very low or nonexistent for graduates in such fields of study as arts and humanities in many systems.

Exploring labor market trajectories of young Europeans from an equity perspective may mean not only linking their labor market trajectories with educational trajectories. It may also increasingly mean linking them with fields of study taken and consequently degrees obtained and used in the labor market. The initial hypothesis is that the socioeconomic background of students and graduates may be positively correlated with fields of study taken: the SES quartiles of origin may be a determining factor for the choice of fields of study, from a continuum of those generally least demanding and least competitive (and leading to the lowest financial rewards in the labor market) to those generally most demanding and most competitive (and leading to best paid jobs).

Researching labor market consequences of studying different fields seems fundamental to linking higher education to the labor market successes and failures (changing employment status and changing occupational status over time) both in individual EU member states and in Europe as a whole. The research literature analyzing the impact of the specific field of study (and its importance for social stratification studies) on occupational prestige, job mismatches, employment status, and income has been growing (see Reimer et al. 2008). As they argue, "with increasing numbers of university graduates in the labor market, the signal value of a university degree from less-academically challenging and less selective fields like the humanities and social sciences will deteriorate" (2008: 234). This is an important additional dimension of studies 
linking higher education to labor markets and labor market trajectories and levels of educational attainment by field of study with wage premium for higher education by field of study. Unfortunately, the EU-SILC dataset does not allow to explore the issue - but it can be approached through the analyses of the European Union Labour Force Survey (EU LFS). The EU-SILC data can also be combined with the European Social Survey (ESS) 2002-2008 data to further explore the issue of linking educational outcomes and occupational outcomes with social background (see Bernardi and Ballarino 2011). At the same time, this is the line of research which can go hand in hand, in empirical terms, with a more fundamental, theoretical issue raised recently by Martha Nussbaum in her Not For Profit: Why Democracy Needs Humanities (2010): that our being in the midst of a "crisis of massive proportions and grave global significance" means a "worldwide crisis in education." In practical terms, the humanities and the arts (as fields of study) being cut away from curricula and are losing their place "in the minds and hearts of parents and children" (Nussbaum 2010: 2). Any research into fields of study should refer to this alarming, global phenomenon. The fate of graduates from those fields in the labor market, from a European comparative perspective, might shed new light on the phenomenon analyzed so far mostly in the American context of liberal education gradually losing its ground.

The second research direction is to study labor market trajectories of young Europeans based on the EU-SILC dataset in combination with other datasets currently available about university graduates and professionals (and can be informed by theoretical underpinning of two large-scale, European comparative research projects of the 2000s - CHEERS and REXLEX, surveys of higher education graduates in Europe (CHEERS) and survey of professionals in Europe (REFLEX), with large theoretical output resulting from both projects. CHEERS studied about 40,000 questionnaires from graduates in 11 European countries and Japan on their socio-biographical background, study paths, transitions from higher education to employment, early career, links between study and employment, job satisfaction, and their retrospective view on higher education (Teichler 2007 and Schomburg and Teichler 2006)). REFLEX studied demands that the modern knowledge society places on higher education graduates and the degree to which higher education equips graduates with the competencies to meet these demands, based on 70,000 surveys of higher education graduates in 15 European countries and Japan (see Allen and van der Velden 2011). The higher education exit point is thus as important as the higher education entry point in current research, so that both students and graduates already present in the labor market are explored. 
And the third research direction is to review the determinants of inequality in workers' lifelong learning (LLL) opportunities on the basis of the EU-SILC. The probability of undertaking lifelong learning (adult learning) can be studied for each EU country, and a European comparative study can be performed directed at LLL incidence, as self-reported by survey respondents. The participation in LLL (and its intensity) is an important dimension of different labor market trajectories of young Europeans, and clusters of countries can be identified on the basis of high/average/low LLL participation - which can be explored through socioeconomic strata of origin of young Europeans. The impact of class origins on LLL participation can be explored although it is unclear whether any links can be shown and whether the equity perspective employed can lead to any statistically significant results. Such dimensions as age, sex, attainment levels, working full or part time, and type of occupation can be researched too, to explore national variations. The EU-SILC data can be combined with such data sources as IALS (the International Adult Literacy Survey), LFS (EU Labour Force Survey), the European Working Conditions Surveys, and the Continuous Vocational Training Survey, as well as OECD aggregate data (see Biagetti and Scicchitano 2009). Lifelong learning is of critical importance for the success of the Europe 2020 strategy, and its role increases with ongoing work in Europe on both National Qualifications Framework and European Qualifications Framework (EQF) which link all levels of (and all routes to) education in EU countries (see Kwiek and Maasen 2012 and Kwiek (2009b)).

Equitable access to higher education and educational and occupational intergenerational social mobility can be studied cross-nationally in Europe through the EU-SILC data, following previous highly successful global research in educational attainment and social stratification (Shavit and Blossfeld 1993; Shavit et al. 2007). Consequently, Europe is consistently becoming a "data-rich" area; a new role of social science research is to use this newly available, large-scale quantitative (and often self-produced) empirical material.

In this new "data-rich" environment, higher education research may increasingly use theoretical insights from the capabilities approach, as it has been using insights from the human capital approach for the last four decades. One of the major obstacles to develop further the capabilities approach in higher education research is the current construction of both national and European datasets, especially their underlying theoretical concepts leading to specific social research vocabulary in data-driven studies. Current datasets "measure" higher education and its multilayered dimensions according to the human 
capital paradigm and therefore, it is hard not to refer to its major concepts, always present behind measures used. And the capability approach in higher education should not rely on qualitative material only, as has been mostly the case so far. If the capability approach is to be applied further to higher education as a sector, it has to highlight not only the need to measure different things but also the need to measure them differently. The whole (national and international) statistical architecture of higher education is currently embedded in the human capital approach. If a new approach is to be further developed within higher education studies, it needs to support both new vocabulary and new statistics, based on new, and most often merely complementary, theoretical concepts.

The paper presents strong support for the "education for all" agenda in Europe: in all European countries, as our data show, access to higher education for young people from lower socioeconomic strata is severely restricted, despite ongoing powerful processes of massification of higher education. For young Europeans from poorer and low-educated backgrounds, the chances to get higher education credentials and to work in highly skilled white-collar occupations are very low indeed, across all European systems (and in Central European systems in particular). It is a shame that in nine European countries, the percentage of people with higher education whose parents had primary education is below $10 \%$; the remaining $90 \%$ of people whose parents had primary education never attained higher education. A major recommendation for EU strategies is to introduce more effective mechanisms to enable new routes of access to, preferably more differentiated, higher education. More diversification in higher education is needed so that a higher proportion of young people from lower socioeconomic strata will be able to move up the education and career ladders in the future. ${ }^{1}$

\footnotetext{
${ }^{1}$ The author gratefully acknowledges the support of the National Research Council (NCN) through its MAESTRO grant DEC-2011/02/A/HS6/00183 (2012-2017). The work on the statistics in this paper would not be possible without the invaluable support of Dr. Wojciech Roszka.
} 


\section{Annex}

Table 6.1 Relative risk ratio for persons from ISCO-88 highest occupational group ("legislators and senior professionals") in relation to their father's occupation (shadowed: "legislators and senior professionals")

\begin{tabular}{|c|c|c|c|c|c|c|c|c|c|}
\hline \multirow{2}{*}{ Country } & \multicolumn{9}{|c|}{ Father's occupation } \\
\hline & 1. LE & 2. $P R$ & 3. TE & 4. $\mathrm{CL}$ & 5. SE & 6. AG & 7. $\mathrm{CR}$ & 8. PL & 9. EL \\
\hline AT & 3.36 & 2.33 & 1.24 & 1.15 & -1.18 & -2.08 & -1.37 & -1.72 & -1.43 \\
\hline $\mathrm{BE}$ & 2.59 & 1.29 & -1.41 & -1.14 & -1.67 & -1.00 & -1.37 & -1.30 & -1.89 \\
\hline $\mathrm{CY}$ & 4.21 & 2.58 & 1.47 & 1.18 & 1.33 & -1.75 & -1.11 & -1.14 & -1.61 \\
\hline $\mathrm{CZ}$ & 2.30 & 2.41 & 1.39 & 1.60 & -1.41 & -1.12 & -1.52 & -1.45 & -1.23 \\
\hline $\mathrm{DE}$ & 1.64 & 1.23 & 1.15 & 1.10 & -1.18 & -1.10 & -1.16 & -1.32 & -2.00 \\
\hline DK & 1.98 & -1.15 & 1.20 & 1.02 & 1.16 & -1.45 & -1.19 & -1.85 & -1.04 \\
\hline $\mathrm{EE}$ & 1.60 & 1.41 & 1.72 & -1.27 & -6.25 & -2.44 & -1.18 & -1.09 & -1.54 \\
\hline ES & 4.12 & 1.13 & 1.21 & -1.00 & -1.32 & -1.22 & -1.47 & -1.35 & -1.52 \\
\hline $\mathrm{FI}$ & 2.12 & 1.35 & 1.06 & -1.01 & 1.09 & -1.33 & -1.05 & -1.28 & -1.79 \\
\hline FR & 2.09 & 1.69 & 1.49 & -1.30 & -1.28 & -1.89 & -1.03 & -1.64 & -1.52 \\
\hline GR & 2.38 & -1.08 & -1.15 & -1.32 & -1.19 & -1.22 & -1.16 & -1.08 & -1.22 \\
\hline $\mathrm{HU}$ & 2.38 & 2.14 & 1.68 & 1.45 & 1.44 & -1.75 & -1.18 & -1.27 & -2.22 \\
\hline $\mathrm{IE}$ & 1.61 & 1.04 & 2.17 & -1.09 & -1.08 & -5.26 & -1.37 & -1.23 & -2.04 \\
\hline IS & 1.42 & 1.08 & 1.19 & 1.14 & -1.64 & -1.59 & -1.00 & -1.05 & 1.24 \\
\hline IT & 2.83 & -1.37 & -1.10 & -1.59 & -1.06 & -1.18 & -1.28 & -1.27 & -1.15 \\
\hline LT & 3.00 & 1.93 & 1.61 & 1.52 & 1.13 & -1.85 & -1.11 & -1.45 & -1.52 \\
\hline $\mathrm{LU}$ & 3.26 & 1.79 & -1.12 & -1.67 & 1.04 & -1.14 & -1.69 & -1.54 & 1.03 \\
\hline LV & 1.24 & 2.23 & 1.22 & 1.06 & 1.83 & 1.04 & -1.11 & -1.23 & -1.43 \\
\hline $\mathrm{NL}$ & 1.56 & -1.19 & -1.09 & 1.03 & -1.01 & -1.00 & -1.56 & -1.23 & -1.00 \\
\hline NO & 1.77 & -1.23 & -1.03 & 1.14 & -1.01 & -1.54 & -1.06 & -1.15 & 1.02 \\
\hline PL & 3.32 & 2.10 & 1.30 & 1.34 & 1.07 & -1.67 & -1.00 & -1.25 & -1.49 \\
\hline PT & 2.58 & 1.58 & 1.02 & -1.52 & 1.31 & -1.28 & -1.20 & -1.43 & -1.00 \\
\hline SE & 3.44 & 1.07 & -1.64 & 1.77 & -2.13 & 1.70 & -2.22 & -1.69 & 1.34 \\
\hline SI & 2.36 & 2.03 & 2.27 & -1.08 & 1.67 & -1.69 & -1.09 & -1.85 & -2.38 \\
\hline SK & 1.86 & 1.62 & 1.28 & 1.31 & -2.22 & -1.67 & -1.18 & -1.27 & -1.02 \\
\hline UK & 1.71 & -1.14 & 1.25 & 1.31 & 1.07 & -1.75 & -1.56 & -1.23 & -1.59 \\
\hline
\end{tabular}

Source: own study based on the EU-SILC 2005 module on "The intergenerational transmission of poverty." ISCO-88 occupational groups (International Standard of Classification of Occupations, 1988, used in EU-SILC) are the following: (1) $L E$ legislators, senior professionals, (2) $P R$ professionals, (3) $T E$ technicians and associate professionals, (4) $C L$ clerks, (5) $S E$ service workers and shop and market sales workers, (6) $A G$ skilled agriculture and fishery workers, (7) $C R$ craft and related trades workers, (8) $P L$ plant and machine operators and assemblers, (9) $E L$ elementary occupations 
Table 6.2 Relative risk ratio for persons from ISCO-88 lowest occupational group (9. "elementary") in relation to their father's occupation (shadowed: (9) "elementary" to (9) "elementary")

\begin{tabular}{|c|c|c|c|c|c|c|c|c|c|}
\hline \multirow{2}{*}{ Country } & \multicolumn{9}{|c|}{ Father's occupation } \\
\hline & 1. $\mathrm{LE}$ & 2. $P R$ & 3. TE & 4. $\mathrm{CL}$ & 5. SE & 6. AG & 7. $\mathrm{CR}$ & 8. PL & 9. EL \\
\hline AT & -1.23 & -2.94 & -1.96 & -2.63 & -1.12 & 1.22 & -1.43 & -1.09 & 2.45 \\
\hline $\mathrm{BE}$ & -2.08 & -3.33 & -2.63 & -2.22 & -1.43 & -1.37 & 1.16 & 1.45 & 3.10 \\
\hline $\mathrm{CY}$ & -2.56 & -6.25 & -4.76 & -3.85 & -1.79 & 1.67 & -1.19 & -1.11 & 1.77 \\
\hline $\mathrm{CZ}$ & -1.89 & -14.29 & -3.03 & -2.86 & -1.30 & 1.51 & 1.01 & 1.20 & 3.06 \\
\hline $\mathrm{DE}$ & -1.47 & -2.27 & -1.30 & -1.69 & -1.23 & 1.60 & 1.07 & 1.56 & 2.03 \\
\hline DK & -1.61 & -4.17 & -1.54 & -1.45 & -1.35 & 1.25 & -1.05 & 1.77 & 1.83 \\
\hline $\mathrm{EE}$ & -1.64 & -2.86 & 1.08 & -1.25 & -1.39 & 1.27 & -1.00 & 1.02 & 1.95 \\
\hline ES & -2.33 & -4.55 & -2.22 & -2.50 & -1.61 & 1.20 & -1.33 & -1.47 & 2.47 \\
\hline $\mathrm{FI}$ & -2.63 & -1.82 & -1.25 & -1.69 & 1.16 & 1.21 & 1.15 & -1.00 & 1.87 \\
\hline$F R$ & -1.41 & -4.00 & -2.08 & -2.56 & -1.19 & 1.36 & 1.10 & 1.13 & 2.09 \\
\hline GR & -2.17 & -2.63 & -1.89 & -1.47 & 1.31 & 1.04 & -1.05 & 1.20 & 2.23 \\
\hline $\mathrm{HU}$ & -2.94 & -9.09 & -4.76 & -2.00 & -1.19 & 1.76 & -1.14 & -1.04 & 2.34 \\
\hline $\mathrm{IE}$ & -1.54 & -1.85 & -1.45 & -2.04 & -2.22 & 1.86 & 1.06 & 1.17 & 2.10 \\
\hline IS & -1.32 & -5.56 & -1.96 & & 1.52 & 1.46 & 1.12 & 1.41 & 1.45 \\
\hline IT & -2.22 & -1.67 & -2.78 & -2.08 & -1.28 & 1.37 & -1.10 & -1.22 & 2.39 \\
\hline LT & -2.50 & -3.57 & -2.78 & -1.23 & -1.04 & 1.15 & -1.15 & 1.05 & 1.63 \\
\hline LU & -2.04 & -20.00 & -2.44 & -5.00 & -1.10 & 1.83 & 1.38 & 1.31 & 1.65 \\
\hline LV & -1.47 & -2.08 & -1.79 & -2.78 & 1.40 & 1.44 & -1.27 & -1.09 & 2.04 \\
\hline $\mathrm{NL}$ & -1.30 & -10.00 & -1.82 & 1.10 & -1.08 & 1.49 & 1.17 & 1.91 & 2.43 \\
\hline NO & -4.35 & -2.70 & -1.30 & -1.89 & 2.08 & 1.81 & -1.01 & 1.53 & -1.10 \\
\hline $\mathrm{PL}$ & -2.08 & -7.14 & -2.50 & -1.92 & -1.64 & 1.11 & 1.03 & 1.03 & 2.11 \\
\hline PT & -3.57 & -3.70 & -3.13 & -2.04 & -1.67 & 1.16 & -1.02 & -1.18 & 2.35 \\
\hline SE & & -3.45 & 1.13 & & 1.61 & 2.33 & 1.07 & -1.23 & 4.91 \\
\hline $\mathrm{SI}$ & -4.55 & -3.03 & -1.72 & -1.22 & -2.38 & 1.45 & -1.00 & 1.08 & 1.78 \\
\hline SK & -3.03 & -2.63 & -3.03 & -1.61 & 1.04 & 1.31 & -1.16 & -1.09 & 2.16 \\
\hline UK & -2.63 & -4.00 & -1.82 & -2.00 & 1.08 & 2.49 & 1.26 & 1.52 & 1.73 \\
\hline
\end{tabular}

Source: own study based on the EU-SILC 2005 module on "The intergenerational transmission of poverty." ISCO-88 occupational groups (International Standard of Classification of Occupations, 1988, used in EU-SILC) are the following: (1) $L E$ legislators, senior professionals, (2) $P R$ professionals, (3) $T E$ technicians and associate professionals, (4) $C L$ clerks, (5) $S E$ service workers and shop and market sales workers, (6) $A G$ skilled agriculture and fishery workers, (7) $C R$ craft and related trades workers, (8) $P L$ plant and machine operators and assemblers, (9) $E L$ elementary occupations

\section{References}

Allen, J., \& van der Velden, R. (2011). The flexible professional in the knowledge society: New challenges for higher education. Dordrecht: Springer.

Altbach, P. G., Reisberg, L., \& Rumbley, L. E. (2010). Trends in global higher education. Tracking an academic revolution. Rotterdam: Sense.

Archer, L., Hutchings, M., \& Ross, A. (2003). Higher education and social class. Issues of exclusion and inclusion. London: RoutledgeFalmer.

Arum, R., Gamoran, A., \& Shavit, Y. (2007). More inclusion than diversion: Expansion, differentiation, and market structure in higher education. In Y. Shavit, R. Arum, \& A. Gamoran (Eds.), Stratification in higher education. A comparative study. Stanford: Stanford University Press. 
Attewell, P., \& Newman, K. S. (Eds.). (2010). Growing gaps. Educational inequality around the world. Oxford: Oxford University Press.

Baranowska, A. (2011). Does horizontal differentiation make any difference? Heterogeneity of educational degrees and labor market entry in Poland. In I. Kogan, C. Noelke, \& M. Gebel (Eds.), Making the transition: Education and labor market entry in central and eastern Europe (pp. 216-239). Stanford: Stanford University Press.

Bernardi, F., \& Ballarino, G. (2011, March 11). Higher education expansion, equality of opportunity and credential inflation: A European comparative analysis. A conference presentation at Human Capital and Employment in the European and Mediterranean Area, Bologna.

Biagetti, M., \& Scicchitano, S. (2009). Inequality in workers' lifelong learning across European countries: Evidence from EU-SILC data-set. MPRA paper no. 17356, available from http:// mpra.ub.uni-muenchen.de/17356/. Accessed 10 Oct 2014.

Bialecki, I., \& Dabrowa-Szefler, M. (2009). Polish higher education in transition: Between policy making and autonomy. In D. Palfreyman \& D. T. Tapper (Eds.), Structuring mass higher education: The role of elite institutions. London: Routledge.

Boni, A., \& Walker, M. (Eds.). (2013). Human development and capabilities. Re-imagining the university of the twenty-first century. London: Routledge.

Breen, R. (Ed.). (2004). Social mobility in Europe. Oxford: Oxford University Press.

Brighouse, H. (2010). Globalization and the professional ethic of the professoriat. In E. Unterhalter \& V. Carpentier (Eds.), Global inequalities and higher education. Whose interests are we serving? (pp. 287-311). London: Palgrave Macmillan.

Brighouse, H., \& Unterhalter, E. (2010). Education for primary goods or for capabilities? In H. Brighouse \& I. Robeyns (Eds.), Measuring justice. Primary goods and capabilities (pp. 193-214). Cambridge: Cambridge University Press.

Brown, P., Lauder, H., \& Ashton, D. (2011). The global auction. The broken promises of education, jobs, and incomes. Oxford: Oxford UP.

Bucharest Communiqué. (2012). Making the most of our potential: Consolidating the European Higher Education Area, Bucharest.

Causa, O., \& Johansson, A. (2009a). Intergenerational social mobility (Economics Department Working Papers No. 707). Paris: OECD.

Causa, O., \& Johansson, A. (2009b). Intergenerational social mobility in European OECD countries (Economics Department Working Papers No. 709). Paris: OECD.

Domański, H. (2000). On the verge of convergence: Social stratification in eastern Europe. Budapest: CEU Press.

EC (2011). Supporting growth and jobs - an agenda for the modernisation of Europe's higher education systems. Brussels: Communication from the European Commission. $\operatorname{COM}(2011) 567 / 2$.

Eurostudent. (2011). Social and economic conditions of student life in Europe. Hannover: HIS.

Flores-Crespo, P. (2007). Situating education in the human capabilities approach. In M. Walker \& E. Unterhalter (Eds.), Amartya Sen's capability approach and social justice in education (pp. 45-66). New York: Palgrave.

Frank, R. H. (2007). Falling behind: How rising inequality harms the middle class. Berkeley: University of California Press.

Hirsch, F. (1976). Social limits to growth. Cambridge: Harvard UP.

Holzer, H., et al. (2011). Where are all the good jobs going? What national and local job quality and dynamics may mean for US workers. New York: Russell Sage.

King, R. (2004). The university in the global age. New York: Palgrave.

Kwiek, M. (2001). The internationalization and globalization in Central and East European Higher Education. Society for Research into Higher Education International News, No. 47, 3-5.

Kwiek, M. (2006). The university and the state. A study into global transformations. Frankfurt am Main/New York: Peter Lang.

Kwiek, M. (2009a). The changing attractiveness of European higher education: Current developments, future challenges, and major policy issues. In B. Kehm, J. Huisman, \& B. Stensaker 
(Eds.), The European higher education area: Perspectives on a moving target (pp. 107-124). Sense: Rotterdam.

Kwiek, M. (2009b). Globalisation: Re-reading its impact on the nation-state, the university, and educational policies in Europe. In M. Simons, M. Olssen, \& M. E. Peters (Eds.), Re-reading education policies. A handbook studying the policy agenda of the 21st century (pp. 195-215). Rotterdam: Sense.

Kwiek, M. (2010). Transformacje uniwersytetu. Zmiany instytucjonalne $i$ ewolucje polityki edukacyjnej w Europie. Poznan: Wydawnictwo Naukowe UAM (in Polish).

Kwiek, M. (2012a). Changing higher education policies: From the deinstitutionalization to the reinstitutionalization of the research mission in Polish universities. Science and Public Policy, 39, 641-654.

Kwiek, M. (2012b). Universities, regional development and economic competitiveness: The Polish case. In P. Benneworth, G. A. Jones, \& R. Pinheiro (Eds.), Universities and regional development. A critical assessment of tensions and contradictions (pp. 69-85). New York: Routledge.

Kwiek, M. (2013a). Knowledge production in European universities. States, markets, and academic entrepreneurialism. Frankfurt/New York: Peter Lang.

Kwiek, M. (2013b). From system expansion to system contraction: Access to higher education in Poland. Comparative Education Review, 57(3), 553-575.

Kwiek, M. (2014). Structural changes in the Polish higher education system (1990-2010): A synthetic view. European Journal of Higher Education, 4(3). Online-first: http://dx.doi.org/10.1080/215 68235.2014 .905965

Kwiek, M., \& Maassen, P. (Eds.). (2012). National higher education reforms in a European context. Comparative reflections on Poland and Norway. Frankfurt/New York: Peter Lang.

London Communiqué (2007). Towards the European higher education area: Responding to challenges in a globalised world. London.

Mach, B. W. (2004). Intergenerational mobility in Poland: 1972-88-94. In R. Breen (Ed.), Social mobility in Europe. Oxford: Oxford University Press.

Marginson, S. (1997). Markets in education. St Leonards: Allen \& Unwin.

Morgan, S. L., Grusky, D. B., \& Fields, G. S. (Eds.). (2009). Mobility and inequality. Frontiers of research in sociology and economics. Stanford: Stanford University Press.

Nussbaum, M. (2010). Not for profit. Why democracy needs the humanities. Princeton: Princeton University Press.

Nussbaum, M. (2011). Creating capabilities. The human development approach. Cambridge: Harvard University Press.

OECD. (2010). Going for growth. Economic policy reforms. Paris: OECD.

OECD. (2011). Education at a glance 2011. OECD indicators. Paris: OECD.

Otto, H.-U. (2009). Social justice and social policies. In K. Schneider \& H.-U. Otto (Eds.), From employability towards capability (pp. 45-54). Luxembourg: Inter-Actions.

Otto, H.-U., \& Ziegler, H. (Eds.). (2010). Education, welfare and the capabilities approach. A European perspective. Opladen/Farmington Hills: Barbara Budrich Publishers.

Reimer, D., Noelke, C., \& Kucel, A. (2008). Labor market effects of field of study in comparative perspective. An analysis of 22 European countries. International Journal of Comparative Sociology, 49(4-5), 233-256.

Schneider, K., \& Otto, H.-U. (Eds.). (2009). From employability towards capability. Luxembourg: Inter-Actions.

Schomburg, H., \& Teichler, U. (2006). Higher education and graduate employment in Europe. Results from graduate surveys from twelve countries. Dordrecht: Springer.

Sen, A. (1999). Development as freedom. Oxford: Oxford University Press.

Shavit, Y., \& Blosfeld, H.-P. (Eds.). (1993). Persistent inequality. Changing educational attainment in thirteen countries. Boulder: Westview Press.

Shavit, Y., Arum, R., \& Gamoran, A. (Eds.). (2007). Stratification in higher education. A comparative study. Stanford: Stanford University Press. 
Teichler, U. (Ed.). (2007). Careers of university graduates. Views and experiences in comparative perspectives. Dordrecht: Springer.

Trow, M. (2007). Reflections on the transition from elite to mass to universal access: Forms and phases of higher education in modern societies since WWII. In J. J. F. Forest \& P. G. Altbach (Eds.), International handbook of higher education. Dordrecht: Springer.

Unterhalter, E. (2010). Considering equality, equity and higher education pedagogies in the context of globalization. In E. Unterhalter \& V. Carpentier (Eds.), Global inequalities and higher education. Whose interests are we serving? (pp. 91-116). London: Palgrave Macmillan.

Unterhalter, E. (2013). What is wrong with Globnal inequality in higher education? In A. Boni \& $\mathrm{N}$. Walker (Eds.), Human development and capabilities. Re-imagining the university of the twenty-first century. London/New York: Routledge.

Unterhalter, E., \& Brighouse, H. (2007). Distribution of what for social justice in education? The case of education for all by 2015. In M. Walker \& E. Unterhalter (Eds.), Amartya Sen's capability approach and social justice in education. New York: Palgrave.

Unterhalter, E., \& Carpentier, V. (2010). Introduction: Whose interests are we serving? global inequalities and higher education. In E. Unterhalter \& V. Carpentier (Eds.), Global inequalities and higher education. Whose interests are we serving? (pp. 1-42). London: Palgrave Macmillan.

Vignoles, A. (2013). Widening participation and social mobility. In C. Callender \& P. Scott (Eds.), Browne and beyond. Modernizing English higher education (pp. 112-129). London: IoE Press.

Walker, M. (2006). Higher education pedagogies. Maidenhead: Open University Press.

Walker, M. (2010a). Capabilities and social justice in education. In H.-U. Otto \& H. Ziegler (Eds.), Education, welfare and the capabilities approach. A European perspective. Opladen/ Farmington Hills: Barbara Budrich Publishers.

Walker, M. (2010b). Pedagogy for rich human being-ness in global times. In E. Unterhalter \& V. Carpentier (Eds.), Global inequalities and higher education. Whose interests are we serving? (pp. 219-240). London: Palgrave Macmillan.

Walker, M., \& Boni, A. (2013). Higher education and human development: Towards the public and social good. In A. Boni \& M. Walker (Eds.), Human development and capabilities. Re-imagining the university of the twenty-first century (pp. 15-29). London: Routledge.

Walker, M., \& Unterhalter, E. (Eds.). (2007). Amartya Sen's capability approach and social justice in education. New York: Palgrave. 